\title{
Economic Evaluation of the UCSRP-HP Process in IGCC Applications
}

\author{
Arunabha Basu ${ }^{*}$, Ajay Makkuni, S. James Zhou, Howard S. Meyer \\ Energy Conversion, Gas Technology Institute, Des Plaines, USA \\ Email: *arun.basu@gastechnology.org
}

Received May 22, 2013; revised June 30, 2013; accepted July 8, 2013

Copyright (C) 2013 Arunabha Basu et al. This is an open access article distributed under the Creative Commons Attribution License, which permits unrestricted use, distribution, and reproduction in any medium, provided the original work is properly cited.

\begin{abstract}
With financial assistance from the US Department of Energy and the Illinois Clean Coal Institute, Gas Technology Institute (GTI) has been working with the University of California, Berkeley, for further development of their UCSRPHP (University of California Sulfur Recovery Process-High Pressure) technology. The key focus of the UCSRP-HP technology is integrated multi-contaminant removal of hydrogen sulfide $\left(\mathrm{H}_{2} \mathrm{~S}\right)$, carbonyl sulfide $(\mathrm{COS})$, ammonia $\left(\mathrm{NH}_{3}\right)$, chlorides and heavy metals present in coal-derived syngas. The process has two major components: 1) removal of various trace components with a solvent (e.g., diethylene glycol or water) using a high-pressure scrubbing unit and 2) removal of $\mathrm{H}_{2} \mathrm{~S}$ as sulfur via reaction with $\mathrm{SO}_{2}$ (in the presence of a solvent mixed a small quantity of a homogeneous catalyst) at $120^{\circ} \mathrm{C}$ to $150^{\circ} \mathrm{C}$ and at any syngas pressure. During this research, data critical to developing and evaluating UCSRP-HP technology for multi-contaminant removal from syngas derived from Illinois \#6 coal were obtained. In this paper, we have presented key economic evaluations of the UCSRP-HP process, including potential integrations with other technology options for $\mathrm{CO}_{2}$ and hydrogen separations, for a nominal Illinois \#6-coal-based 550-MW $\mathrm{MW}_{\mathrm{e}}$ Integrated Coal Gasification Combined Cycle (IGCC) facility with $\mathrm{CO}_{2}$ capture and sequestration. GTI is exploring various options to demonstrate this technology in a pilot plant using actual syngas from a coal gasifier.
\end{abstract}

Keywords: UCSRP-HP Technology; IGCC Power Plants; Synthesis Gas Clean-Up; IGCC Economics; Carbon Capture and Sequestration

\section{Introduction}

Based on various estimates [1] on future global energy requirements, the combined share of key fossil fuels such as coal, oil and natural gas would continue to increase and could represent approximately $80 \%$ by 2030 . A major use of coal would continue to be electric power generation. In the context of concerns related to environmental issues including climate change, several coal gasification technologies are currently being developed that would require low-cost removal of key contaminants including $\mathrm{H}_{2} \mathrm{~S}, \mathrm{NH}_{3}, \mathrm{HCl}$, and various heavy metals as well as carbon capture, utilization and sequestration (CCUS) of $\mathrm{CO}_{2}$ from syngas. For the use of this coal-derived syngas under a CCUS scenario as a fuel for a gas turbine or further processing to key chemicals, such as methane (for sale as synthetic natural gas), liquid fuels, or hydrogen, these contaminants including $\mathrm{CO}_{2}$ should be reduced to very low values.

\footnotetext{
Corresponding author.
}

\subsection{Conventional Technologies for $\mathrm{CO}_{2}$, Sulfur Compounds and Trace Contaminants Removal}

In estimating the cost of electricity using coal gasification integrated with carbon capture, the US Department of Energy (DOE) had outlined the use of following proven technologies for the removal of key contaminants [2]. A schematic of the overall process (referred to as the DOE Base Case 2) is shown in Figure 1.

- The hot gasifier syngas would be typically cooled from $\sim 1315^{\circ} \mathrm{C}$ to $\sim 590^{\circ} \mathrm{C}$ using a radiant gas cooler for the removal of molten slag as solids particles that include ash and unconverted carbon particles. The waste-heat from this cooling is used to generate highpressure steam.

- The syngas is then processed in a water quench/ scrubbing step along with a sour-water stripper for the removal of entrained solids including chlorides. The water stripper would primarily remove ammonia, $\mathrm{SO}_{2}$ and some of the trace metals. The exit syngas tem- 
perature from this step is $\sim 205^{\circ} \mathrm{C}$. The wastewater is send to a treatment plant.

- The syngas would then be mixed with steam for processing in a two-stage Sour Gas Shift (SGS) unit to convert over $95 \%$ of the carbon monoxide to $\mathrm{CO}_{2}$. The SGS catalyst also serves to hydrolyze any COS (carbonyl sulfide) that may be present in the syngas, to $\mathrm{CO}_{2}$ and $\mathrm{H}_{2} \mathrm{~S}$. The SGS effluent (at $\sim 270^{\circ} \mathrm{C}$ ) is then cooled to $\sim 38^{\circ} \mathrm{C}$ for the separation of entrained water that may contain some trace metals and residual ammonia, chlorides. The water would be processed in the sour water stripper mentioned above.

- The cooled syngas would then be treated in a carbon bed for the removal of about $95 \%$ of the mercury. Eastman Chemical Company has used specific carbon-bed systems in their coal gasification plant at Kingsport, Tennessee, for the removal of mercury.

- For the removal of $\mathrm{H}_{2} \mathrm{~S}$ and $\mathrm{CO}_{2}$ from the syngas, a two-stage Selexol ${ }^{\mathrm{TM}}$ process can be utilized where $\mathrm{H}_{2} \mathrm{~S}$ is removed in the first stage of absorbance and $\mathrm{CO}_{2}$ in the second stage. This AGR (Acid Gas Removal) step would result in three product streams: 1) a $\mathrm{H}_{2}$-rich clean syngas, 2) a $\mathrm{CO}_{2}$-rich stream (which would be sequestered) and 3$)$ an acid-gas rich ( $45 \%$
$\mathrm{CO}_{2}, 40 \% \mathrm{H}_{2} \mathrm{~S}, 8 \%$ nitrogen) stream which would then be processed in a Claus plant to produce sulfur. The $\mathrm{H}_{2}$-rich gas $\left(\sim 90 \% \mathrm{H}_{2}\right)$ would be used as a fuel in a gas turbine for the generation of electricity.

\subsection{Specific Advanced Technologies for the Removal of $\mathrm{CO}_{2}$, Sulfur Compounds and Trace Contaminants}

\subsubsection{GTI's UCSRP-HP Technology for the Removal of Trace Contaminants and $\mathrm{H}_{2} \mathrm{~S}$ (US Patent \#8241603)}

The UCSRP-HP technology has two key processing steps as shown in Figure 2.

- Removal of trace contaminants: In bench-scale experiments at GTI, we have shown effective removal of mercury, selenium and ammonia in a counter-current packed column using Diethylene Glycol (DEG) as a solvent [3]. For GTI's economic evaluations, we have assumed that the removal of a majority of the trace contaminants with sour-water can be significantly improved by using a High-pressure Water Contactor for treating partially cooled $\left(\sim 65^{\circ} \mathrm{C}-120^{\circ} \mathrm{C}\right)$ high-pressure syngas in a down-flow co-current reac-

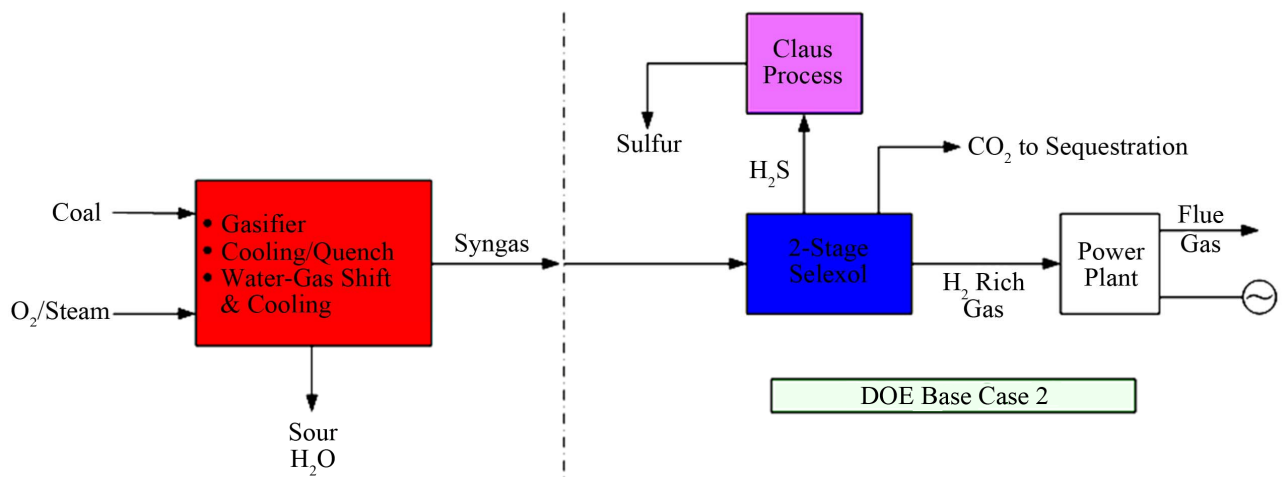

Figure 1. Overall process schematic for DOE Base Case 2 [2].

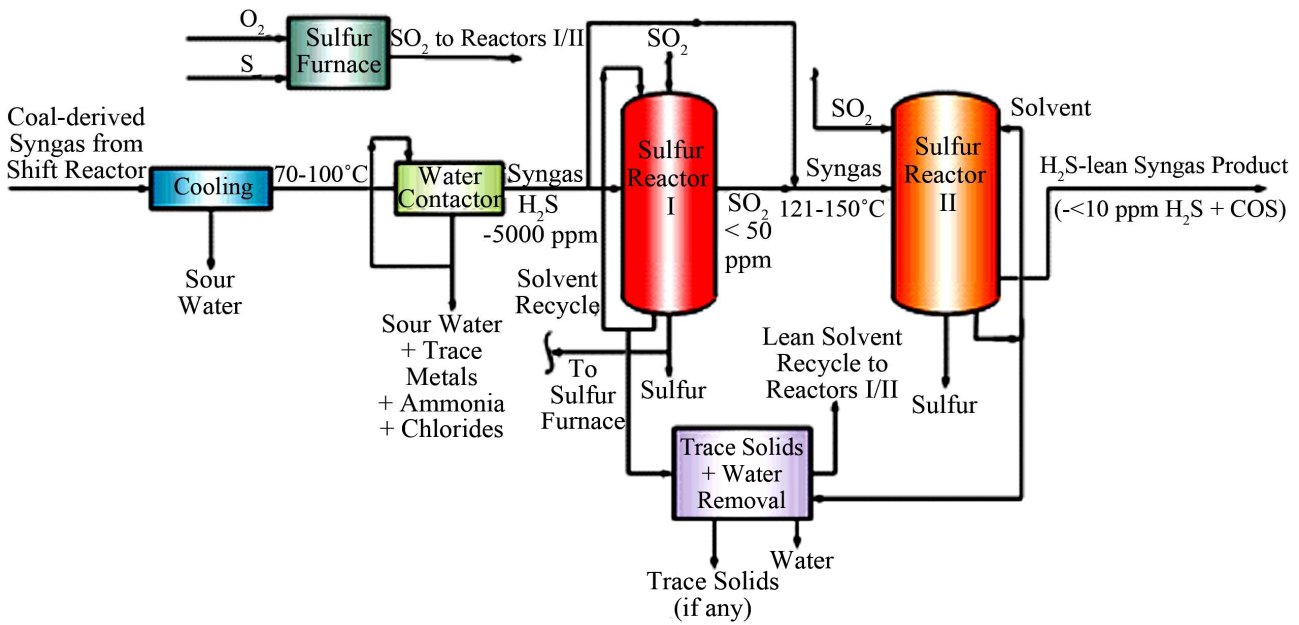

Figure 2. Two-stage sulfur-reactor concept for the UCSRP-HP technology. 
tor fitted with high-surface area Sulzer $\mathrm{SMV}^{\mathrm{TM}}$ packing [4]. In this concept, the scrubbed syngas would be removed from the bottom of the unit for processing in the downstream sulfur-removal reactor. A slipstream of the circulating water would be withdrawn and filtered for the removal of water-insoluble solids. The filtrate will be treated in a stripper to remove 1) any dissolved ammonia/ $\mathrm{H}_{2} \mathrm{~S}$ for additional processing and 2) the water for processing in a wastewater treatment plant.

- $\mathrm{H}_{2} \mathrm{~S}$ removal: $\mathrm{H}_{2} \mathrm{~S}$ would be removed via the liquidphase Claus reaction (where $\mathrm{H}_{2} \mathrm{~S}$ is reacted with $\mathrm{SO}_{2}$ at $\sim 120^{\circ} \mathrm{C}-150^{\circ} \mathrm{C}$, in the presence of a liquid solvent (e.g., DGM: Diethylene Glycol Methyl Ether) mixed with a homogeneous catalyst (e.g., 3-pyridinemethnol), to form elemental sulfur plus water: $2 \mathrm{H}_{2} \mathrm{~S}+\mathrm{SO}_{2}$ $=3 \mathrm{~S}+2 \mathrm{H}_{2} \mathrm{O}$. The $\mathrm{SO}_{2}$ requirement for the reaction with $\mathrm{H} 2 \mathrm{~S}$ would be supplied by the combustion of about one-third of the sulfur product with oxygen. The reactor column temperature would be maintained at about $120^{\circ} \mathrm{C}-150^{\circ} \mathrm{C}$ to ensure that the temperature is above the melting point $\left(\sim 120^{\circ} \mathrm{C}\right)$ and below the polymerization temperature $\left(\sim 155^{\circ} \mathrm{C}\right)$ of elemental sulfur. At these operating conditions, as liquid sulfur is essentially immiscible in DGM solvent and over twice as dense, it is removed as a separate product from the reactor column. In the GTI two-stage concept (schematic shown in Figure 2), the first-stage would be operated in the "excess- $\mathrm{SO}_{2}$ mode" whereas the second-stage would be operated in the "excess$\mathrm{H}_{2} \mathrm{~S}$ mode" to enhance the reaction kinetics in forming sulfur (+water) in both of these reactors; here, "excess" is referred to as $\sim 1 \%-10 \%$ extra reactant $\left(\mathrm{SO}_{2}\right.$ or $\left.\mathrm{H}_{2} \mathrm{~S}\right)$ than that required by the Claus reaction stoichiometry.

In the UCSRP-HP process for IGCC electric power generation, the $\mathrm{H}_{2} \mathrm{~S}$ level in product syngas to a gas turbine would be limited to about 5 - 8 ppmv acceptable for modern gas turbines. For special applications involving the conversion of syngas to chemicals, hydrogen and clean gaseous/liquid fuels, the $\mathrm{H}_{2} \mathrm{~S}$ level in product syngas would be reduced to below 50 ppbv. Details of the UCSRP-HP have been published previously [4,5]. Testing done at GTI has shown negligible chemical consumption (including catalyst) vs. typical costs of $\$ 300$ $\$ 1000$ per ton sulfur removed required in competing processes. There is much less need for stainless steels in the process, and no apparent cut-off point in terms of sulfur handling at which Claus/SCOT becomes more economical. This process differs from liquid redox processes in important ways. There is no need for filtering a solid sulfur paste with attendant handling problems and loss of solvent. The sulfur quality can be as good as Claus sulfur due to the low solubility of the solvent in the liquid sulfur.

\subsubsection{RTI Warm Syngas Cleanup Technology for the Removal of Trace Metals Components and $\mathrm{H}_{2} \mathrm{~S} / \mathrm{COS}$}

The RTI technology is currently being developed for the removal of heavy metals and $\mathrm{H}_{2} \mathrm{~S} / \mathrm{COS}$ from coal-derived syngas [6]. A key advantage of this technology relates to the use of relatively high operating temperature of $\sim 455^{\circ} \mathrm{C}$. RTI, Eastman Chemicals and DOE have completed pilot plant demonstration of the technology; plans are currently underway for a larger scale demonstration (at $~ 50 \mathrm{MW}$-scale) at Tampa Electric's (TECO) Polk Power Station in Polk County, FL. In this process, various proprietary adsorbents are used for the removal of trace metals. For the removal of sulfur compounds, multiple processing steps (consisting of HTDS and DSRP units) are used with solids recirculation, as outlined by the following key chemical reactions:

The HTDS (High Temperature Desulfurization) step has two key units, the absorber and regenerator.

- Absorber Unit ( $\mathrm{ZnO}$ as the sorbent):

$$
\mathrm{H}_{2} \mathrm{~S}+\mathrm{ZnO}=\mathrm{ZnS}+\mathrm{H}_{2} \mathrm{O}
$$

- Sorbent Regenerator Unit:

$$
\mathrm{ZnS}+1.5 \mathrm{O}_{2}=\mathrm{ZnO}+\mathrm{SO}_{2}
$$

The DSRP (Direct Sulfur Recovery Process) step also has two primary stages:

- Direct Sulfur Recovery (DSRP) Unit, Stage 1: The $\mathrm{SO}_{2}$ from the regenerator is reduced to elemental sulfur via the reactions

$$
\begin{gathered}
\mathrm{SO}_{2}+2 \mathrm{CO}=2 \mathrm{CO}_{2}+\mathrm{S} \\
\mathrm{SO}_{2}+2 \mathrm{H}_{2}=2 \mathrm{H}_{2} \mathrm{O}+\mathrm{S}
\end{gathered}
$$

Direct Sulfur Recovery (DSRP) Unit, Stage 2: The tail gas from DSRP-1 is then sent to the DSRP-2 where the residual $\mathrm{SO}_{2}$ is hydrogenated to $\mathrm{H}_{2} \mathrm{~S}$ via

$$
\mathrm{SO}_{2}+3 \mathrm{H}_{2}=\mathrm{H}_{2} \mathrm{~S}+2 \mathrm{H}_{2} \mathrm{O}
$$

The $\mathrm{H}_{2} \mathrm{~S}$-rich product from this step is cooled before recycling to the HTDS step.

\subsubsection{GTI-Porogen Carbo-Lock Technology for the Separation of $\mathrm{CO}_{2}$}

Gas Technology Institute (GTI) and PoroGen Corporation are jointly developing a novel hybrid membraneabsorption process for pre- and post-combustion $\mathrm{CO}_{2}$ capture (Carbo-Lock ${ }^{\mathrm{TM}}$ process) [7]. The novel CarboLock $^{\mathrm{TM}}$ process combines beneficial features of both absorption and membrane technologies for cost-effective separation and capture of $\mathrm{CO}_{2}$ from various emission sources. The Carbo-Lock ${ }^{\mathrm{TM}}$ process is a hybrid of membrane and the conventional absorption processes. $\mathrm{CO}_{2}$ containing gas passes through small membrane tubes (hollow fibers with porous walls), while a $\mathrm{CO}_{2}$-selective 
solvent (e.g., an amine solution) flows on the shell side of the membrane tubes. $\mathrm{CO}_{2}$ passes through the nanoporous membrane and is absorbed in the selective solvent. The $\mathrm{CO}_{2}$-rich solvent can then be regenerated in a second membrane module operated in a reverse process. The Carbo-Lock $^{\mathrm{TM}}$ process uses a novel hollow fiber membrane technology patented by PoroGen. This novel membrane is made from a chemically and thermally stable commercial engineered polymer poly (ether ether ketone) or PEEK. The PEEK membrane contactor can provide a platform for solvent-based systems beyond conventional amines. The reduced size requirements translate to lower solvent inventories, less metal exposure to corrosive liquids, and lower overall footprint. The system operates at very low gas pressure drops, comparable to those achieved with very large diameter columns, and much lower than those of conventional membrane systems.

\subsubsection{SRI/LANL Technology for the Separation of $\mathrm{CO}_{2}$}

SRI International [8] and LANL (Los Alamos National Laboratory, [9]) are developing specific membranes from hollow fibers of a temperature-resistant (up to $\sim 400^{\circ} \mathrm{C}$ ) and sulfur-tolerant polybenzimidazole (PBI) polymer with $\mathrm{H}_{2} / \mathrm{CO}_{2}$ selectivity of $\sim 20-40$. PBI material has a relatively high melting point that does not readily ignite, because of its exceptional thermal and chemical stability. As an example, the SRI membrane can be used to separate coal-derived syngas (at $\sim 700-800 \mathrm{psig}$ and $\sim 250^{\circ} \mathrm{C}$ ) into two products: 1) a mixture of $\mathrm{H}_{2}$ /steam plus a sweep-gas (e.g., $\mathrm{N}_{2}$ in IGCC applications), at 250 - 450 psia and $\sim 250^{\circ} \mathrm{C}$, for processing in a gas turbine, and 2) a $\mathrm{CO}_{2}$-rich stream (containing $\mathrm{H}_{2} \mathrm{~S}$ plus other trace components) at about the feed-gas pressure and $\sim 250^{\circ} \mathrm{C}$. Following removals of the sulfur and trace components, the $\mathrm{CO}_{2}$ stream can be processed for compression and sequestration.

\subsubsection{Eltron Inc. Membrane Technology for the Separation of Hydrogen from $\mathrm{CO}_{2}$}

Various R \& D activities, including those by Eltron Inc., are continuing to develop effective membranes in separating $\mathrm{H}_{2}$ from $\mathrm{CO}_{2}$ in coal gasification applications. According to Eltron [10], their densemetal membrane can:

- Enable $\sim 95 \%$ - 99\% carbon capture under specific syngas cleanup scenarios.

- Maintain the product $\mathrm{CO}_{2}$ at near feed pressure to minimize compression cost for sequestration.

- Produce a relatively high-pressure $\mathrm{H}_{2}$ stream with over $90 \%$ hydrogen recovery and near $100 \%$ purity.

- $\mathrm{Be} \sim 10 \mathrm{x}$ less expensive than a typical Pd-membrane used for separating $\mathrm{H}_{2}$ and would have $\sim 10 \mathrm{x}$ better performance.

Specific pilot plant demonstrations (at $\sim 12-200 \mathrm{lb} /$ day scale) of the Eltron $\mathrm{H}_{2}$-membrane technology are currently under way with financial support from Eastman Chemicals and the US-DOE. Eltron's R \& D plans include Pre-Commercial Module (PCM; 5 - 10 tons/day $\mathrm{H}_{2}$ ) scale demonstrations.

\section{Results and Discussions}

\subsection{Economic Potential for the UCSRP-HP Technology in Coal Gasification Applications with $\mathrm{CO}_{2}$ Capture}

The economic potential of the UCSRP-HP process for IGCC-based electric power generation with $\mathrm{CO}_{2}$ capture (Case A: Table 1) in a nominal 550-MW plant was evaluated. Another power plant design case (Case-A-1) was also evaluated where the product syngas has a sulfur level below $50 \mathrm{ppbv}$ as would be required for applications involving the production of various chemicals and liquid/gaseous fuels. The process design for Case A was based on the DOE Case 2 of "Cost and Performance Baseline for Fossil Energy Plants" [2]. Table 2 shows the contaminant targets for the two GTI cases. The UCSRP-HP cases were designed for the "Chemicals" specifications in both cases except for the $\mathrm{H}_{2} \mathrm{~S}$ level. In the Case $\mathrm{A}$, the $\mathrm{H}_{2} \mathrm{~S}$ concentration in the feed gas to the gas turbine was $\sim 8 \mathrm{ppm}$ (vs. $<50 \mathrm{ppb}$ for Case A-1). The low level required the addition of a COS hydrolysis reactor and a guard-bed added to the IGCC case as noted later.

The UCSRP-HP Design Case A keeps the DOE Case 2 design up through the first heat exchanger (HP Steam) in the Gas Cooling, BFW Heating \& Knockout block where the syngas feed is at $\sim 53$ bar and $232^{\circ} \mathrm{C}$. This is downstream of the Quench and Scrubber Section and the Water Gas Shift Reactors. The DOE Case 2 is rejoined at the feed to the $\mathrm{CO}_{2}$ removal section of the dual-stage Selex$\mathrm{ol}^{\mathrm{TM}}$ unit. This design replaces or eliminates the Mercury Removal, $\mathrm{H}_{2} \mathrm{~S}$-removal section of the dual stage Selex$\mathrm{ol}^{\mathrm{TM}}$ unit, the Claus Plant, and Hydrogenation Reactor and Gas Cooler Section. Schematic of the UCSRP-HP Base Case design (Case A) is shown in Figure 3. For Case $\mathrm{A}$, the total $\mathrm{SO}_{2}$ emission from the IGCC power plant is about $34 \mathrm{lb} / \mathrm{hr}$ (115 tonne/y) vs. $56 \mathrm{lb} / \mathrm{hr}$ (190 tonne/y) specified in the DOE Case 2.

The syngas stream from the HP Steam heat exchanger is further cooled to $75^{\circ} \mathrm{C}$ and then processed in a highpressure, co-current, down-flow Water Contactor unit to separate a large fraction of water present in the gas along with much of the $\mathrm{NH}_{3}$ and essentially all of the halogens and heavy metals, as sulfides or water-soluble salts. The sour gas feed enters Water Contactor, where it is contacted with a stream of circulating water. At the pressure, temperature, and water content of the syngas, the circulating water will have a steady-state content of $\mathrm{NH}_{3}$ and 
Table 1. Design cases and technologies used in the economic evaluations of various process pathways.

\begin{tabular}{|c|c|c|c|}
\hline Cases & Description & $\mathrm{H}_{2} \mathrm{~S}$ removal option & $\mathrm{CO}_{2}$ removal option \\
\hline Case 1 & $\begin{array}{l}\text { DOE Case 1: This case represents a nominal net } 550 \mathrm{MW} \text { IGCC plant with no } \mathrm{CO}_{2} \\
\text { capture [2] using sulfur impregnated carbon beds for mercury removal, single-stage } \\
\text { Selexol }{ }^{\mathrm{TM}} \text { for } \mathrm{H}_{2} \mathrm{~S} \text { removal, and Claus/Tail Gas for sulfur recovery. }\end{array}$ & Selexol $^{\mathrm{TM}}$ & None \\
\hline Case 2 & $\begin{array}{l}\text { DOE Case 2: This case (schematic shown in Figure 1) represents a nominal net } 550 \mathrm{MW} \\
\text { IGCC plant with } \mathrm{CO}_{2} \text { capture [2] using the conventional cold gas cleanup (CGCU) } \\
\text { scheme with sulfur impregnated carbon beds for mercury removal, dual-stage Selexol } \\
\text { process for the removal of } \mathrm{H}_{2} \mathrm{~S} \text { and } \mathrm{CO}_{2} \text {, and Claus/Tail Gas for sulfur recovery. }\end{array}$ & Selexol $^{\mathrm{TM}}$ & Selexol $^{\mathrm{TM}}$ \\
\hline Case A & $\begin{array}{l}\text { This case (Figure 3) uses DOE Case } 2 \text { and incorporates UCSRP-HP for multi-contaminant } \\
\text { removal with conventional Selexol }{ }^{\mathrm{TM}} \text { process for } \mathrm{CO}_{2} \text { removal as mentioned earlier. }\end{array}$ & UCSRP-HP & Selexol $^{\mathrm{TM}}$ \\
\hline Case B & $\begin{array}{l}\text { This case (Figure 4(a)) uses Case A (UCSRP-HP) with } \\
\text { GTI/PoroGen's CarboLock membrane contactor }[7,14] \text { with Selexol }{ }^{\mathrm{TM}} \text { for } \\
\mathrm{CO}_{2} \text { removal rather than conventional columns. }\end{array}$ & UCSRP-HP & $\begin{array}{l}\text { GTI/PoroGen } \\
\text { CarboLock Membrane } \\
\text { Contactor w/Selexol }^{\mathrm{TM}}\end{array}$ \\
\hline Case C & $\begin{array}{l}\text { This case (Figure } 4(\mathbf{b}) \text { ) is the published SRI study [8] that uses LANL/SRI's PBI } \\
\text { membrane for hydrogen/acid gas separation and purification of the } \mathrm{CO}_{2} \text { stream by a } \\
\text { single-stage Selexol }{ }^{\mathrm{TM}} / \text { Claus/Tail Gas process for sulfur recovery. The syngas from the } \\
\text { Water-Gas Shift (WGS) is first processed for } \mathrm{CO}_{2} \text { plus } \mathrm{H}_{2} \mathrm{~S} \text { removal in a PBI membrane; } \\
\text { the } \mathrm{CO}_{2} \text {-rich stream is then processed in a Single-stage Selexol }{ }^{\mathrm{TM}} \text { unit for } \mathrm{H}_{2} \mathrm{~S} \text { removal. }\end{array}$ & Selexol $^{\mathrm{TM}}$ & $\begin{array}{l}\text { LANL/ SRI PBI } \\
\text { Membrane }\end{array}$ \\
\hline Case D & $\begin{array}{l}\text { This case (Figure } \mathbf{4}(\mathbf{b})) \text { uses Case } \mathrm{C} \text { and incorporates UCSRP-HP for } \\
\text { multi-contaminant removal downstream of LANL/SRI's PBI membrane } \\
\text { rather than the Selexol }{ }^{\mathrm{TM}} / \text { Claus/Tail Gas trains. }\end{array}$ & UCSRP-HP & $\begin{array}{l}\text { LANL/SRI PBI } \\
\text { Membrane }\end{array}$ \\
\hline Case E & $\begin{array}{l}\text { This case (Figure 4(a)) is the published DOE/Noblis report }[15,16] \text { that uses RTI's } \\
\text { warm gas cleanup (WGCU) process for multi-contaminant removal and } \\
\text { a single-stage Selexol }{ }^{\mathrm{TM}} \text { process for } \mathrm{CO}_{2} \text { capture. }\end{array}$ & RTI & Selexol ${ }^{\mathrm{TM}}$ \\
\hline Case F & $\begin{array}{l}\text { This case (Figure 4(c)) is the published DOE/Noblis report }[15,16] \text { that uses RTI's } \\
\text { WGCU process for multi-contaminant removal and an Advanced } \mathrm{H}_{2} \text { Membrane } \\
\text { (performance projections by DOE/Noblis }[12] \text { for } \mathrm{CO}_{2} \text { removal. }\end{array}$ & RTI & $\begin{array}{l}\text { Advanced } \mathrm{H}_{2} \\
\text { Membrane }\end{array}$ \\
\hline Case G & $\begin{array}{c}\text { This case (Figure 4(c)) uses Case } \mathrm{A} \text { and incorporates an Advanced } \mathrm{H}_{2} \\
\text { Membrane for } \mathrm{H}_{2} / \mathrm{CO}_{2} \text { separation [12]. }\end{array}$ & UCSRP-HP & Advanced $\mathrm{H}_{2}$ Membrane \\
\hline
\end{tabular}

Table 2. Design targets for contaminants.

\begin{tabular}{cc}
\hline Contaminant & Maximum after cleanup \\
\hline $\mathrm{H}_{2} \mathrm{~S}$ & $8 \mathrm{ppm}$ for Case $\mathrm{A} ; 50 \mathrm{ppbv}$ for Case A- ${ }^{1}$ \\
$\mathrm{NH}_{3}$ & $0.1 \mathrm{vol} \%$ \\
$\mathrm{HCl}$ & $1 \mathrm{ppm}$ \\
$\mathrm{Hg}$ & $5 \mathrm{ppbw}$ \\
$\mathrm{Se}$ & $0.2 \mathrm{ppm}$ \\
$\mathrm{As}$ & $5 \mathrm{ppb}$ \\
$\mathrm{Cd}$ & $30 \mathrm{ppb}$ \\
\hline
\end{tabular}

${ }^{1}$ For Design Case A, the $\mathrm{H}_{2} \mathrm{~S}$ level in the feed gas to the gas turbine is 8 ppmv, and the total $\mathrm{SO}_{2}$ emission is $34 \mathrm{lb} / \mathrm{h}$.

$\mathrm{H}_{2} \mathrm{~S}$. As a result, the $\mathrm{HCl}$ content of the feed gas will be absorbed very effectively to form highly soluble $\mathrm{NH}_{4} \mathrm{Cl}$. A small but significant concentration of $\mathrm{NH}_{4} \mathrm{HS}$ will also be present in the liquid phase and the heavy metals As, $\mathrm{Cd}$ and $\mathrm{Hg}$ will be absorbed to form their respective, insoluble sulfides. Selenium will be present in the syngas as $\mathrm{H}_{2} \mathrm{Se}$ and will be absorbed to form highly soluble $\left(\mathrm{NH}_{4}\right)_{2} \mathrm{Se}$ under these conditions. At the bottom of the scrub contactor, the water stream is withdrawn and circulated by pump back to the top after dissolved gases are flashed and returned to the feed gas stream. A slipstream of the water stream will be withdrawn for filtration and other treatments to remove the accumulated impurities, and then sent to the sour water stripper forwater treatment; the overhead sour gases from the stripper will be compressed and mixed with the syngas feed to the UCSRP reactor. Following this Water Contactor unit, the gas is preheated to about $120^{\circ} \mathrm{C}$ prior to its processing in the UCSRP-HP reactor. The key objective for the removal of a large fraction of the water prior to the UCSRP-HP reactor in this specific design case is to minimize the cost of separation of water from DGM solvent used in the reactor. In future, other design options for the separation of water and DGM from the UCSRP reactor effluent(s) will be evaluated.

An Aspen Plus ${ }^{\circledR}$ simulation UCSRP-HP model was prepared to identify a co-current, down-flow contactor reactor design that is simple and less expensive to build compared to the original counter-current designs. A DGM slipstream is treated by hydro cyclones to remove any precipitated heavy metal salts that may not have been removed by the water filter. To be conservative, the design cases assume that some COS is formed within the UCSRP-HP reactor system. The sulfur is separated, filtered by a DURCO sulfur filter, and sent to a sulfur pit or 


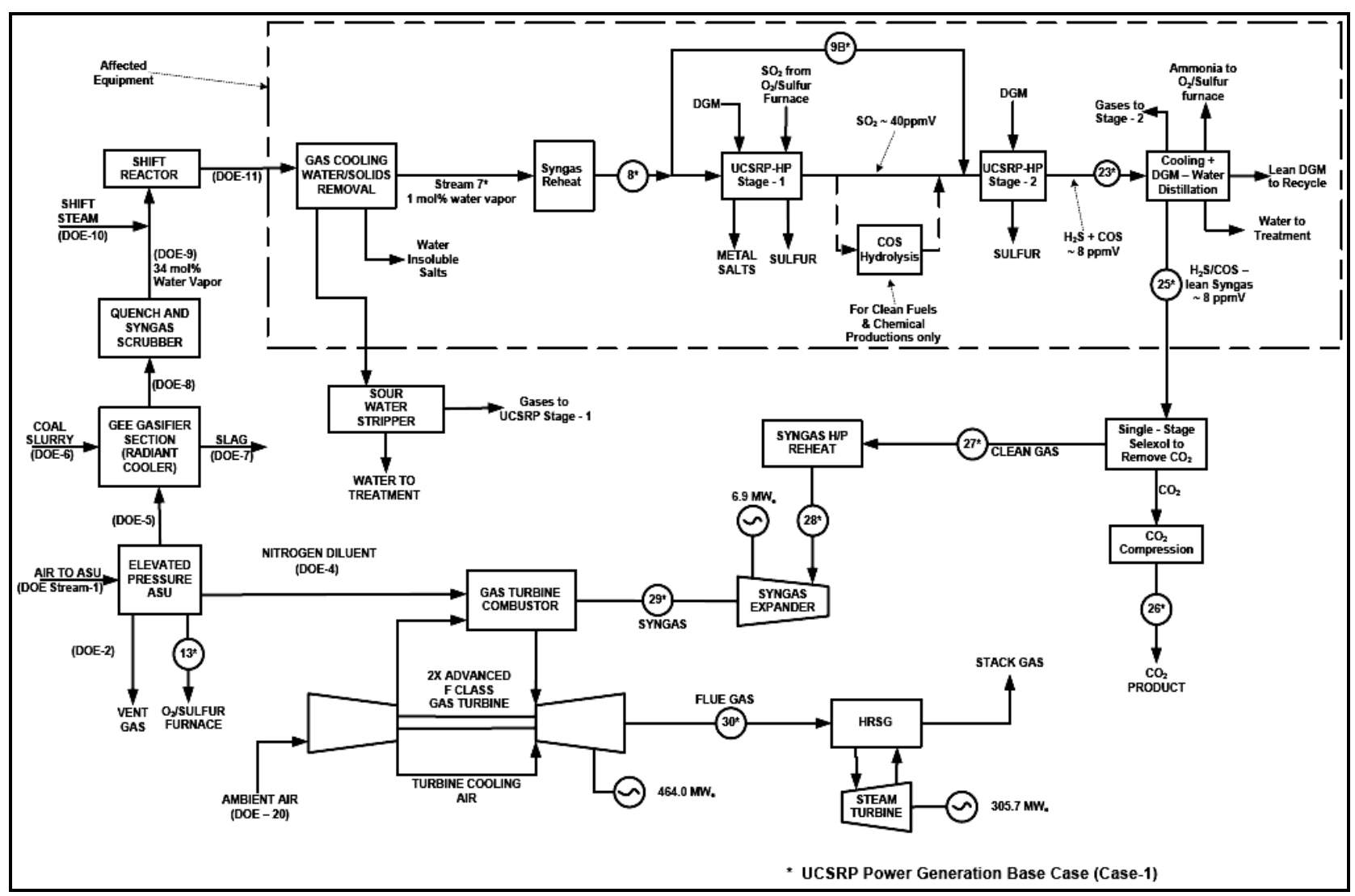

Figure 3. GTI UCSRP-HP Base Case (Design Case A) with $\mathrm{CO}_{2}$ capture (Total $\mathrm{SO}_{2}$ emission: $34 \mathrm{lb} / \mathrm{hr}$ and near zero for chemicals case, Case A-1).

to a commercial-design $\mathrm{O}_{2}$ /sulfur submerged combustion furnace [11], as needed to generate the required liquid $\mathrm{SO}_{2}$ for reaction with $\mathrm{H}_{2} \mathrm{~S}$ in the UCSRP-HP reactors. Ammonia from the DGM distillation unit is also fed to the sulfur furnace and converted to $\mathrm{N}_{2}$ and $\mathrm{H}_{2} \mathrm{O}$ as it passes through the furnace. The combustion gas raises steam in the boiler and then passes through the condenser, where liquid sulfur is collected. The wet $\mathrm{SO}_{2}$ gas then flows to a cooler, where liquid water, saturated with dissolved $\mathrm{SO}_{2}$, is condensed. The $\mathrm{SO}_{2}$ stream leaving the cooler is converted to liquid in another condenser, and then pressurized to the pressure of the reactor column by a pump.

The product syngas from the UCSRP-HP reactor is cooled to about $32^{\circ} \mathrm{C}$ for 1) heat integration and 2) minimization of the loss of DGM solvent with the product syngas delivered to the IGCC plant. The cooled gas is sent to a high-pressure separator to recover DGM solvent that is processed in a distillation unit to remove the water 1) formed in the reactor due to the reaction of $\mathrm{H}_{2} \mathrm{~S}$ and $\mathrm{SO}_{2}, 2$ ) present in the syngas feed to the reactors and 3) provide a lean DGM supply to the reactor. For the Chemicals case, to achieve the $<50$ ppb sulfur target, a COS hydrolysis unit is introduced in the UCSRP-HP reactor system to produce a syngas containing about 7.6 ppm $\mathrm{H}_{2} \mathrm{~S}$ and 0.4 ppm COS. A zinc oxide guard-bed is also added downstream of the high-pressure separator to reduce the total sulfur level to $<50 \mathrm{ppb}$ in the effluent gas. If COS is shown not to form, the COS hydrolysis unit can be eliminated and the zinc oxide guard bed can be made smaller. To be conservative, there are three means to collect the heavy metals in the process. One is primarily by using water filters in the Water Removal unit. The other two backup means involve the use of DURCO liquid sulfur filter, and hydro cyclone/precipitation filters to process a slipstream of the recycle DGM solvent from the UCSRP-reactor. If further experimentation shows that all of the heavy metals are collected in the Water Removal unit as solid sulfides, the backup means can be eliminated. The sweet, cooled syngas is then transferred, as in the DOE Case 2 design, to the $\mathrm{CO}_{2}$ removal section of the dual-stage Selexol ${ }^{\mathrm{TM}}$ unit and the power island.

\subsection{Process Economics}

The methodology given in the referenced DOE report was followed to evaluate the UCSRP-HP process. Relative to the results for the DOE Case 2 that uses conventional cold gas cleanup scheme with Selexol ${ }^{\mathrm{TM}} / \mathrm{Claus} /$ Tail Gas-type $\mathrm{H}_{2} \mathrm{~S}$ removal processes, the study shows 


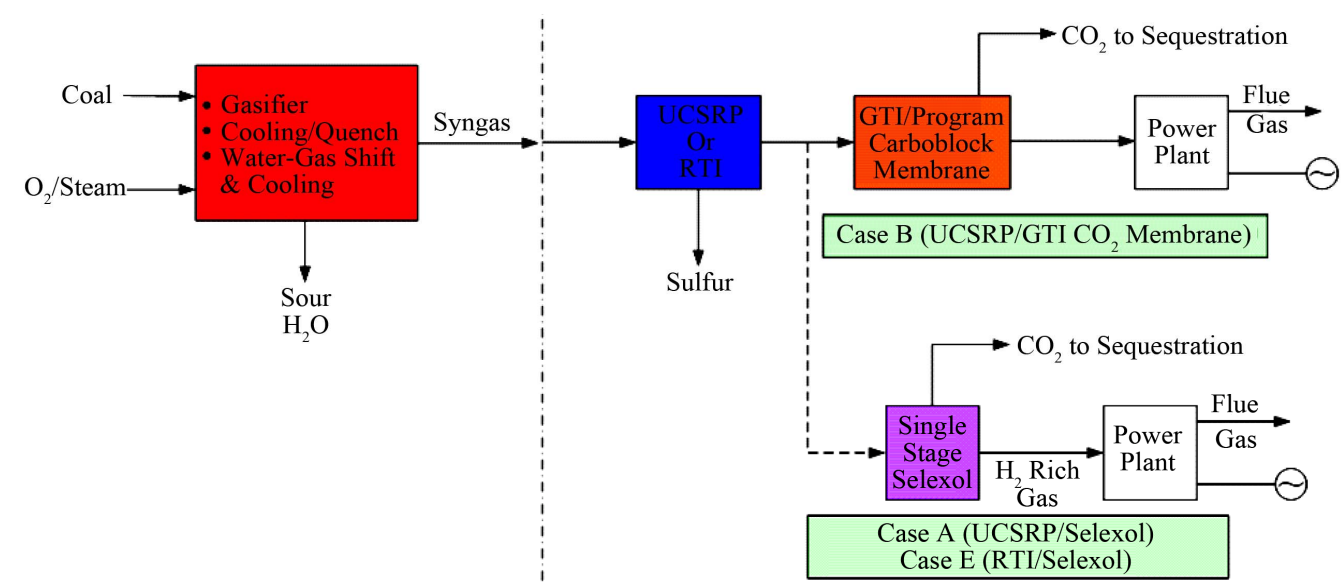

(a)

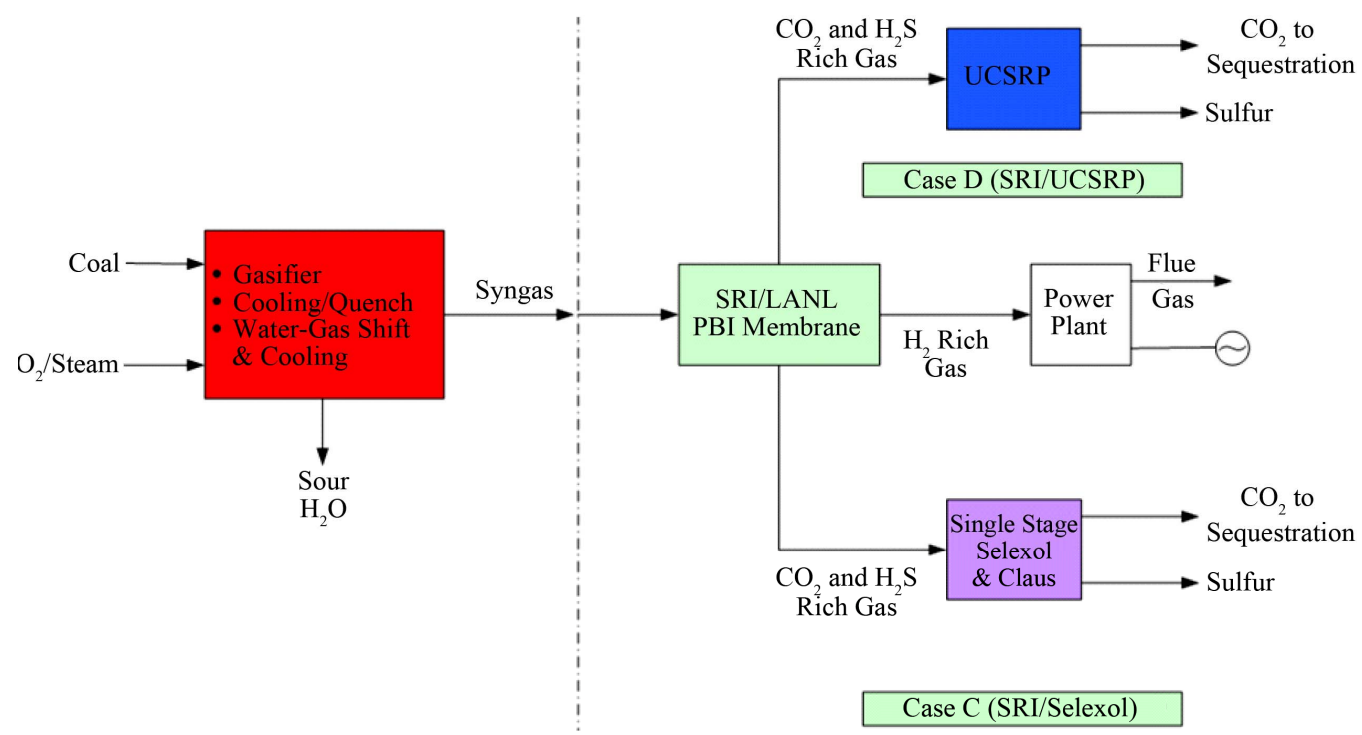

(b)

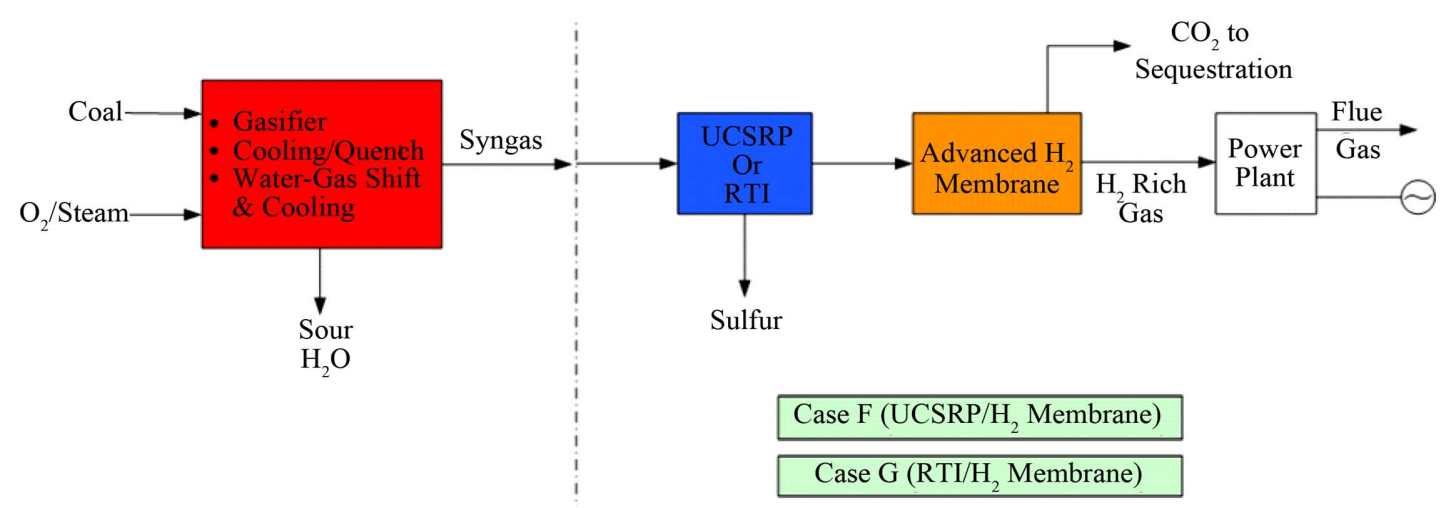

(c)

Figure 4. Overall process schematics: (a) Cases A, B, and E; (b) Cases C and D; (c) Cases F and G.

significant economic and environmental advantages (see Table 3) for the UCSRP-HP Base Case design:

- A net CAPEX savings of about \$123 MM (Dec'06 dollars) based on the conservative design and $\pm 30 \%$ cost estimate basis; key details on the comparative
CAPEX data for the two designs are given in Table 4.

- The overall thermal efficiency (HHV basis) would increase from about $32.5 \%$ for the DOE Case 2 to about $33.5 \%$ for the UCSRP-HP design. 
Table 3. Comparative COE data: DOE Case 2 vs. UCSRPHP.

\begin{tabular}{|c|c|c|c|}
\hline & DOE Case 2 & $\begin{array}{c}\text { GTI } \\
\text { UCSRP-HP } \\
\text { Base Case }\end{array}$ & $\begin{array}{c}\text { GTI } \\
\text { UCSRP-HP } \\
\text { Chemicals case }\end{array}$ \\
\hline $\begin{array}{c}\text { Coal Feed Rate, dry, } \\
\text { lb/hr }\end{array}$ & 444,737 & 444,737 & 444,737 \\
\hline $\mathrm{SO}_{2}$ Emissions $(\mathrm{lb} / \mathrm{hr})$ & 56 & 34 & $\sim 0$ \\
\hline Gas Turbine, MWe & 464.0 & 464.0 & 464.0 \\
\hline $\begin{array}{l}\text { Sweet Gas Expander, } \\
\text { MWe }\end{array}$ & 6.3 & 6.3 & 5.8 \\
\hline Steam Turbine, MWe & 274.7 & 287.5 & 287.5 \\
\hline Total Auxiliaries, MWe & -189.3 & -184.5 & -184.5 \\
\hline $\begin{array}{c}\text { Net Power for Sale, } \\
\text { MWe }\end{array}$ & 555.7 & 573.3 & 572.8 \\
\hline $\begin{array}{c}\text { Thermal Efficiency, \% } \\
\text { (HHV) }\end{array}$ & 32.5 & 33.5 & 33.4 \\
\hline $\begin{array}{l}\text { Total CAPEX, \$MM } \\
(\text { Yr-2006 \$) }\end{array}$ & 1328 & 1205 & 1215 \\
\hline $\begin{array}{l}\text { Cost of Power, } \$ / M W h r \\
\text { (or, mills } / \mathrm{kWh})^{1}\end{array}$ & 103.0 & 93.4 & 95.2 \\
\hline
\end{tabular}

${ }^{1}$ DOE Economic Model to determine LCOE: Levelized Cost of Electricity [2].

Table 4. Comparative data on CAPEX: DOE Case 2 vs. UCSRP-HP Base Case.

\begin{tabular}{ccc}
\hline Case & DOE IGCC Case 2 & GTI UCSRP-HP \\
\hline Dry Coal feed rate, $\mathrm{lb} / \mathrm{hr}$ & 444,737 & 444,737 \\
Total $\mathrm{SO}_{2}$ emission, $\mathrm{lb} / \mathrm{hr}$ & 56 & 34 \\
\hline
\end{tabular}

\begin{tabular}{ccc} 
Total $\mathrm{SO}_{2}$ emission, lb/hr & 56 & 34 \\
\hline \multicolumn{2}{c}{ Total Plant Cost, \$MM (Dec. 2006 \$) } \\
\hline Plant Area 5A Gas Cleanup & 172.0 & 70.0 \\
5A.1 Selexol System ${ }^{*}$ & 32.8 & - \\
5A.2 Elemental Sulfur plant & 3.2 & - \\
5A.3 Mercury Removal & - & 14.6 \\
5A.5 UCSRP & \\
Affected subtotal & 208.0 & 84.6 \\
Remaining Area 5 Items & 21.9 & 21.9 \\
Area 5A Total & 229.9 & 106.5 \\
Remainder of Plant & 1098.3 & 1098.3 \\
Total Plant Cost & 1328.2 & 1204.8 \\
Capital Savings & & 123.4 \\
\hline
\end{tabular}

*Selexol System: DOE IGCC Case 1-Single-Stage $\mathrm{H}_{2} \mathrm{~S}$ removal $(43,585$ $\mathrm{lbmol} / \mathrm{hr}, \$ 80.8 \mathrm{MM})$; DOE IGCC Case 2-Dual-Stage $\mathrm{H}_{2} \mathrm{~S}$ and $\mathrm{CO}_{2}$ removal $(62,118 \mathrm{lbmol} / \mathrm{hr}, \$ 172 \mathrm{MM})$; UCSRP-HP—Single-Stage $\mathrm{CO}_{2}$ removal only; Cost of the single-stage $\mathrm{H}_{2} \mathrm{~S}$ removal process would be $\$ 80.8 \mathrm{x}$ $(62,118 / 43,585) 0.65=\$ 102 \mathrm{MM}$; Cost of the single-stage $\mathrm{CO}_{2}$ removal process would be $(\$ 172-102 \mathrm{MM})=\$ 70 \mathrm{MM}$.
- An increase of about 17.6 MW ( 3.2\%) in net power sale.

- A reduction of about $\$ 9.60 / \mathrm{MWhr}(\sim 9.3 \%)$ in the cost of electricity (COE) production with carbon capture, $\mathrm{CO}_{2}$ compression plus transport/storage/monitoring; and

- A reduction in total $\mathrm{SO}_{2}$ emission of about $22 \mathrm{lb} / \mathrm{hr}$ (74 tonne/y).

In addition, preparing the syngas for a Chemicals application that requires $<50 \mathrm{ppb}$ sulfur in the syngas would increase the COE by about $\$ 1.80 / \mathrm{MWhr}$ if the syngas was used for power generation in a near zero $\mathrm{SO}_{2}$ discharge IGCC plant.

Table 5 provides a comparison of the overall plant performance for the DOE Case 2 and the UCSRP-HP Base Case. The power production was set the same for both plants. The difference in saleable power is the difference in the auxiliary load. As seen here, the Claus Plant Tail Gas Recycle Compressor, first stage Selexol Unit Auxiliaries, and the Claus Plant/Tail Gas Unit Auxiliaries consumed $4751 \mathrm{kWe}$ more than the UCSRP Units and Sulfur Furnace. This resulted in a modest efficiency increase for the UCSRP-HP from about $32.5 \%$ for the

Table 5. Plant performance summary.

\begin{tabular}{|c|c|c|}
\hline & DOE Case 2 & $\begin{array}{c}\text { UCSRP-HP Base } \\
\text { case (Design Case A) }\end{array}$ \\
\hline Dry Coal Feed Rate, lb/hr & 444,737 & 444,737 \\
\hline Total Thermal Input, kWt & $1,710,780$ & $1,710,780$ \\
\hline \multicolumn{3}{|l|}{ Power Summary, kWe } \\
\hline Gas Turbine Power & 464,010 & 464,010 \\
\hline Sweet Gas Expander Power & 6260 & 6260 \\
\hline Primary Steam Turbine Power & 274,690 & 287,500 \\
\hline Total Power Generation, kWe & 744,960 & 757,770 \\
\hline \multicolumn{3}{|l|}{ Auxiliary Load Summary, kWe } \\
\hline $\begin{array}{c}\text { Claus Plant Tail Gas Recycle } \\
\text { Compressor }\end{array}$ & 990 & 0 \\
\hline Selexol Unit Aux. & 17,320 & 12,445 \\
\hline Claus Plant/TGTU Aux. & 200 & 0 \\
\hline $\begin{array}{c}\text { UCSRP Units }+ \text { Sulfur } / \mathrm{O}_{2} \\
\text { Furnace }\end{array}$ & - & 1314 \\
\hline Balance of Plant & 170,775 & 170,775 \\
\hline Total Auxiliaries, kWe & 189,285 & 184,534 \\
\hline NET POWER, kWe & 555,675 & 573,236 \\
\hline $\begin{array}{c}\text { Net Extra Power Production, } \\
\text { kWe }\end{array}$ & - & 17,561 \\
\hline $\begin{array}{c}\text { Total Thermal Input in Coal } \\
\text { Feed, kWt }\end{array}$ & $1,710,780$ & $1,710,780$ \\
\hline Net Plant Efficiency, \% (HHV) & 32.5 & 33.5 \\
\hline
\end{tabular}


DOE Case 2 to about $33.5 \%$ for the UCSRP-HP Base Case design.

\subsection{Economic Potential for the Integration of Key Membrane Technologies for the Removal of $\mathrm{CO}_{2}$ and $\mathrm{H}_{2}$ with the UCSRP-HP in IGCC Applications}

The economic potential of integrating UCSRP-HP with 1) the LANL/SRI's PBI (polybenzimidazole), high-temperature $\left(\sim 250^{\circ} \mathrm{C}-450^{\circ} \mathrm{C}\right)$, polymeric $\mathrm{CO}_{2}$-removal membrane, 2) the GTI/PoroGen's CarboLock Membrane for $\mathrm{CO}_{2}$ removal, and 3) an advanced $\mathrm{H}_{2}$-separation membrane that would meet specific year-2015 performance targets [12] assumed by DOE/Noblis LLC were also examined. For these economic evaluations, it is assumed that the $\mathrm{CO}_{2}$ product would need to meet the KinderMorgan specifications for existing commercial $\mathrm{CO}_{2}$ pipelines [13]. These cases were compared to the published data on RTI's warm gas cleanup (WGC) process. The salient features of these various designs cases are summarized in Table 1. The schematic flow diagrams of the design cases A, B. C, D, E, F and G are shown in Figure 4.

The COE data for these integration options are compared in Table 6 with those derived from literature information. As shown in Table 6, both the RTI and the UCSRP-HP process integration options with an advanced hydrogen membrane appear to be quite promising in reducing the overall COE for future IGCC plants that would include CCUS.

Figure 5 shows how various developmental technologies affect the cost of electricity (see Table 1 for related design cases). The horizontal line marked " 1 " is the COE without carbon capture (Case 1). Point " 2 " is the base case for carbon capture using "conventional" capture technology (Case 2). The line 2-A-B-G represents incorporating UCSRP-HP for multi-contaminant removal with Selexol ${ }^{\mathrm{TM}}$ for $\mathrm{CO}_{2}$ removal (Case A), GTI/PoroGen's CarboLock membrane contactor with Selexol ${ }^{\mathrm{TM}}$ rather than conventional columns for $\mathrm{CO}_{2}$ removal (Case B), and an Advanced $\mathrm{H}_{2}$ membrane for $\mathrm{CO}_{2}$ removal (Case G). Line 2-C-D represents incorporating the PBI membrane for $\mathrm{H}_{2}$ /acid gas separation with purification of the $\mathrm{CO}_{2}$ stream by a single-stage Selexol ${ }^{\mathrm{TM}} /$ Claus/Tail Gas process for sulfur recovery (Case C) and UCSRP-HP for multi-contaminant removal (Case D). Line 2-E-F represents incorporating WGCU for multi-contaminant removal with a single-stage Selexol ${ }^{\mathrm{TM}}$ for $\mathrm{CO}_{2}$ removal (Case E) and an Advanced $\mathrm{H}_{2}$ membrane for $\mathrm{CO}_{2}$ removal (Case F). These cases show that UCSRP-HP can make a positive impact with new developmental technologies and become a viable alternative to competing multicomponent cleanup technologies.
Table 6. Comparative data for $\mathrm{COE}$ (including $\mathrm{CO}_{2}$ capture, compression, transport, plus storage/monitoring).

\begin{tabular}{ccc}
\hline Design Case & COE, \$/MWhr & COE Differential, \% \\
\hline DOE-1 & 77.8 & Base \\
DOE-2 & 103.0 & 32.4 \\
Case A & 93.4 & 20.1 \\
Case B & 91.7 & 17.9 \\
Case C & 98.2 & 26.2 \\
Case D & 94.7 & 21.7 \\
Case E & 101.6 & 30.6 \\
Case F & 89.6 & 15.2 \\
Case G & 88.8 & 14.2 \\
\hline
\end{tabular}

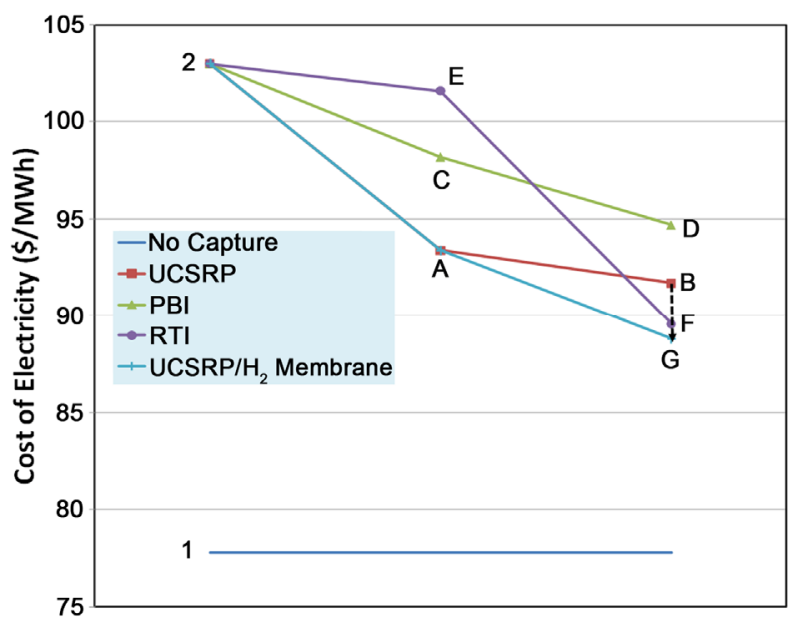

Figure 5. Comparative data for COE using multiple technology pathways and integrations.

\section{Conclusions}

The key conclusions of this study are:

- For economic evaluations of various novel technologies for sulfur removal and carbon capture in IGCC applications, estimates for $\mathrm{COE}$ would depend on overall thermal efficiency for power generation as well as the capital cost requirements.

- As an example, the RTI WGCU technology for sulfur removal has demonstrated relatively high thermal efficiency; however, based on the DOE/ NETL estimates, the COE with carbon capture for Case E (RTI WGCU with single-stage Selexol ${ }^{\mathrm{TM}}$ for carbon capture) has been estimated at only $\sim 1.4 \%$ lower relative to the DOE Case 2 (CGCU with two-stage Selexol ${ }^{\mathrm{TM}}$ ).

- In contrast, for Case A (using the UCSRP-HP technology for sulfur removal and the single-stage Selexol ${ }^{\mathrm{TM}}$ for carbon capture), a COE reduction of 
$\sim 9.1 \%$ relative to the DOE Case 2 is estimated. This can be attributed to the significant savings in capital cost for the UCSRP-HP process due to its relative simplicity.

- As indicated in the Design Case $G$, integration of the UCSRP-HP process for sulfur removal with an Advanced $\mathrm{H}_{2}$ Membrane for $\mathrm{H}_{2} / \mathrm{CO}_{2}$ separation could lead to a $\mathrm{COE}$ value that would be only about $15 \%$ higher than DOE's baseline cost projections (in DOE Case 1) for a no carbon capture IGCC plant.

- The COE for Case $\mathrm{G}$ is similar (at about $15 \%$ increase relative to the no carbon capture case) to that estimated by DOE/Noblis for the Case F using the RTI process for sulfur removal and the advanced $\mathrm{H}_{2}$ Membrane process for $\mathrm{CO}_{2}$ removal.

- The UCSRP-HP technology may offer significant economic advantages over competing technologies in monetizing high-sulfur coals (e.g., Illinois basin coals).

\section{Acknowledgements}

This paper is based upon work supported by the Department of Energy National Energy Technology Laboratory under Award Number DE-FC26-05NT42458, and by the Illinois Clean Coal Institute with funds made available through the Office of Coal Development of the Illinois Department of Commerce and Economic Opportunity. The authors acknowledge the support and guidance of Jenny Tennant, DOE-NETL, Francois Botha and Debalina Dasgupta, ICCI, Dennis Leppin and Jim Wangerow, GTI, and Professor Scott Lynn, UC, Berkeley on this technology development.

\section{REFERENCES}

[1] BP Energy Outlook 2030, Slide 10, 2011. http://www.bp.com/liveassets/bp_internet/globalbp/global bp_uk_english/reports_and_publications/statistical_energ y_review_2008/STAGING/local_assets/2010_downloads /2030_energy_outlook_booklet.p̄pdf

[2] Research and Development Solutions LLC., and Parsons Corp., "Cost and Performance Baseline for Fossil Energy Plants," DOE/NETL-2007/1281, August 2007.

[3] H. S. Meyer, "Development of an Integrated Multi-Contaminant Removal Process Applied to Warm Syngas Cleanup for Coal-Based Advanced Gasification Systems," Vol. 1, DOE Project \# DE-FC26-05NT42458, Reporting Period: June 2005-November 302010.

[4] H. S. Meyer, "Integrated, Multi-Contaminant Removal Process for Syngas Cleanup_Phase 3," ICCI Project Number 10/2A-1, 2010.

[5] A. Basu, H. S. Meyer, D. Leppin, J. Zhou and A. Mak- kuni, "UCSRP-A Flexible Sulfur Removal Process for Sweetening Natural Gas," American Institute of Chemical Engineers Spring Meeting, Houston, 1-5 April 2012. http://www.aiche-fpd.org/listing/127.pdf

[6] http://www.rti.org/brochures/rti_adv_gasification.pdf

[7] S. Li, D. J. Rocha, S. J. Zhou, H. S. Meyer, B. Bikson and Y. Ding. "Post-Combustion $\mathrm{CO}_{2}$ Capture Using SuperHydrophobic, Polyether Ether Ketone, Hollow Fiber Membrane Contactors," Journal of Membrane Science, Vol. 430, 2013, pp. 79-86. doi:10.1016/j.memsci.2012.12.001

[8] Krishnan, G., "Fabrication and Scale-Up of Polybenzimidazole (PBI) Membrane Based System for Pre-Combustion Based Capture of Carbon Dioxide," 2011 NETL $\mathrm{CO}_{2}$ Capture Technology Meeting, Pittsburgh, 22-26 August 2011.

http://www.netl.doe.gov/publications/proceedings/11/co2 capture/presentations/5-Friday/26Aug11-Krishman-SRIPBI\%20Membranes\%20for\%20Pre-Combustion\%20Capt ur.pdf

[9] K. A. Berchtold, et al., "High Temperature PolymerBased Membrane Systems for Pre-Combustion Carbon Dioxide Capture," NETL $\mathrm{CO}_{2}$ Capture Technical Meeting, Pittsburgh, 9-12 July 2012.

http://www.netl.doe.gov/publications/proceedings/12/co2 capture/presentations/4-Thursday/K\%20Berchtold-LANLPolymer-based\%20Membrane.pdf

[10] D. Jack, et al., "Scale-Up of Hydrogen Transport Membranes for Carbon Capture Applications," Gasification Technology Conference, San Francisco, 9-12 October 2011. http://www.netl.doe.gov/technologies/coalpower/gasificat ion/projects/adv-sep/42469/40JACK.pdf

[11] R. L. Schendel, " $\mathrm{SO}_{2}$-Generation Process Can Double Refinery Claus Unit Capacity," The Oil and Gas Journal, 1993, pp. 63-66.

[12] D. Gray and J. Plunkett, "Personal Communication on Mass/Energy Balances and Cost Data for Advanced $\mathrm{H}_{2}$ Membrane," 2010.

[13] K. Havens, " $\mathrm{CO}_{2}$ Transportation," Indiana Center for Coal Technology Research, Slide 14, 2008.

https://www.purdue.edu/discoverypark/energy/assets/pdfs /cctr/presentations/Havens-CCTR-June08.pdf

[14] S. J. Zhou, et al., "Hybrid Membrane/Absorption Process for Post-Combustion $\mathrm{CO}_{2}$ Capture," NETL $\mathrm{CO}_{2}$ Capture Technology Meeting, Pittsburgh, 13-17 September 2010. http://www.netl.doe.gov/publications/proceedings/12/co2 capture/presentations/1-Monday/J\%20Zhou-GTI-Hybrid\% 20Membrane\%20Process.pdf

[15] DOE/NETL Report, "Current and Future Technologies for Gasification-Based Power Generation,” DOE/NETL Report 2009/1389, Vol. 2, 2009, pp. 3-17.

[16] DOE/NETL Report, "Current and Future Technologies: A Pathway Study Focused on Non-Carbon Capture Advanced Power Systems R \& D using Bituminous Coal,' Vol. 1, DOE NETL-2008/1337, 2008, pp. 3-18. 